\title{
Retraction Note: Effects of Nano-particles on Histo-pathological changes of the fish
}

\author{
Ali Louei Monfared ${ }^{1} \cdot$ Ali Mohammad Bahrami ${ }^{1} \cdot$ Ehsan Hosseini $^{1} \cdot$ Salman Soltani ${ }^{2} \cdot$ Minoo Shaddel $^{3}$
}

Published online: 30 May 2019

(C) Springer Nature Switzerland AG 2019

\section{Retraction Note: J Environ Health Sci Engineer https://doi.org/10.1186/s40201-015-0216-9}

The authors have retracted this article [1] because it has been previously published [2]. All authors agree with this retraction.

1. Monfared AL, Bahrami AM, Hosseini E, Soltani S, Shaddel M. Effects of Nano-particles on Histo-pathological changes of the fish. J Environ Health Sci Eng 2015 13: 62

2. Monfared AL, Soltani S. Histological, Histometric and biochemical alterations of the gill and kidney of rainbow trout (Oncorhynchus mykiss) exposed to silver nanoparticles. Eur J Exp Biol 2013, 3(2):391-395

Publisher's note Springer Nature remains neutral with regard to jurisdictional claims in published maps and institutional affiliations.

The online version of the original article can be found at https://oi.org/ 10.1186/s40201-015-0216-9

Minoo Shaddel

min_shad@yahoo.com

1 Faculty of Para-Veterinary Medicine, University of Ilam, Ilam, Iran

2 Master of Sciences of Histology, Faculty of Veterinary Medicine, University of Shahid Chamran Ahwaz, Ahwaz, Iran

3 Department of Parasitology, Faculty of Medicine, Aja University of Medical Sciences, Tehran, Iran 